\title{
Policy of Permission of Permit To Exit Indonesia's Region In Immigration Perspective
}

\author{
Syakir \\ Human Resource Development on Ministry of Law and Human Rights (Mol\&HR), Address, City and Post \\ Code, Indonesia
}

Email: Syakir59sumali@gmail.com

\section{ARTICLE INFO}

Date received : 20 July 2020 s

Revision date : 15 August 2020

Date received : 16 September 2020

\section{Keywords:}

Immigration

Traffic

Selective Policy

Exit Sign

Departure Prevention.

\begin{abstract}
In the Immigration Law No. 6 of 2011 concerning Immigration Immigration is the matter of the traffic of people entering and leaving the Indonesian Territory and its supervision in order to maintain the upholding of the country's sovereignty, in the sense that we need to underline the word traffic, in immigration means synonymous with the movement of people, when speaking history at the beginning of the leadership of the immigration department at the time of the transition from the Dutch government to the Indonesian government adheres to the immigration law policy is open (open door) to selective (selective policy) for the national interest, in the case of traffic there is an inspection carried out by immigration officials who have absolute authority in carrying out their functions to provide entry or exit signs for Indonesian Citizens and Foreign Citizens (Foreigners) . Immigration checks by immigration officials facts in the field not all who want to enter or exit must be given permission, of course there is a legal basis or discretion in the implementation, for example when the departure of Indonesian citizens who want to work abroad and foreigners want to leave the territory of Indonesia, are prevented each month on departure, selective policy policies have a security and prosperity approach in that they can not only screen people who want to come to the Region Indonesia, based on the data obtained by researchers that there will be an explanation in there is a policy (selective policy) which we have been unaware of and we have applied for a long time that a selective policy exists on departure which results in people not getting an exit sign and then prevented in the future. appointment.
\end{abstract}

\section{INTRODUCTION}

Indonesia as an independent and sovereign country continues to strive to improve the quality of its life in all aspects of the life of the nation and state. The government in its implementation is required to be able to organize a government that always puts the interests and welfare of its people first. This is in accordance with what is stated in the preamble of the 1945 Constitution of the Republic of Indonesia: (Arifin, 2018) As stated in article 1 paragraph (3) of the 1945 Constitution it states that "the State of Indonesia is a constitutional state".1 
This means the law as the lifeblood of the life of the nation and the law has a strategic and dominant position in the life of the nation and state.

The globalization flow of the world has had an impact on increasing traffic of people and goods between countries, so that State boundaries are more easily penetrated by various human interests, such as trade, industry, tourism, etc. This phenomenon is of concern to countries in the world, to regulate the traffic of people who will enter and leave the country's territory, and to visit or to stay temporarily.

In this case, the authority is the Directorate General of Immigration and immigration checks. in Indonesia it has existed since the Dutch colonial era, at that time there was a body a colonial government called Immigration Dients which was authorized to handle immigration issues for the entire Dutch East Indies region. At first, the political direction of immigration law was open (open door policy) for the benefit of the colonial government and turned into an immigration law selective policy. Based on Indonesia's national interests since the new Head of the Immigration Bureau Mr. HJ Adiwinata (Santoso, 2007).

In this case, it is important to safeguard the sovereignty of the State, from other things that may harm the nation as a result of crossing people. To maintain the integrity of the state, it is important for the state to implementations selective policy against people who enter and leave Indonesian territory.

The selective policy in immigration check for every person who enters and leaves Indonesian territory, not only people, means of transportation, and the person in charge, also does not escape immigration control and inspection at Immigration Checkpoints (TPI) air through airports, sea through ports, land through Border Post (PLBN), as well as other places designated by the competent authorities.

The implementation of selective policies carried out by the government is closely related to the sovereignty of a country. In the developing theory of Sovereignty, according to Jean Bodin, he is known as the father of sovereignty theory which formulates sovereignty that sovereignty is the highest imperative in a state: "A supreme necessity in a country, where sovereignty is owned by the state and is the main characteristic that distinguishes state organizations from organizations. others within the country. Because sovereignty is the highest authority that is not limited by law than the ruler over his citizens and other people in his territory.

Whereas its application in positive law, the selective immigration policy is included in Part One of the Elucidations of Law Number 6 of 2011 concerning Immigration which explains that: "Based on a selective policy that upholds the value of human rights, the entry of foreigners into the territory is regulated. Indonesia, likewise for foreigners who obtain a Tinggai Permit in Indonesian territory must be by the intent and purpose of being in Indonesia. Based on the policy referred to and to protect the national interest, only foreigners who provide benefits and do not endanger public security and order are allowed to enter and reside in Indonesian territory. "In principle, this selective policy requires that: only useful foreigners are allowed to enter and reside in Indonesian territory (Immigration, n.d.).

Based on this principle, only foreigners can provide benefits for the welfare of the people, nation, and state, do not endanger security and order, and are not hostile towards the people who can enter and leave Indonesian territory(Indra, 2010).

Furthermore, this selective policy in its implementation should consider the balance between the security approach(security approach) and welfare(prosperity approach) (Sfahriful, n.d.). Herein lies the multidimensional position of the agency immigration bearer as of the function of law enforcement, guardian of state sovereignty, and facilitator of community welfare development.

Operationally the role of immigration can be translated into the concept of immigration trifunctional. Where this concept intends to state that the immigration system, whether viewed from the culture of immigration law, legal material (legal regulations), institutions, organizations, apparatus, immigration law mechanisms, immigration law facilities, and infrastructure, in its operation must always contain trifunctional, namely:

a. Community service function

b. Law Enforcement Function

c. Security Function.

\section{METODE}

The method used must be accompanied by a reference; relevant modifications should be described. Data analysis procedures and techniques should be emphasized in the literature review article. The stages and analysis of the research should be described in detail.

\section{RESULTS AND DISCUSSION}

\section{Application of selective policy in Positive Law in Indonesia}

\section{Definition of Selective Policy}

Elective Policy (Selective Policy) is inseparable from immigration, where the term immigration comes from Latin, migration which means the movement of people from one place or country to another place or country, and there is also the term emigration which means different, namely the movement of 
people from one place or another. territories or countries to other territories or countries.

The history of the development of immigration in Indonesia starts from the period before independence and the period after independence, where the period after independence until now the existence of immigration in Indonesia is very much needed to guarantee the benefits and protect various national interests. The legislation was established by the Colonial Government and partly formed after the Proclamation of 17 August 1945. In addition to the presence of various scattered laws and regulations, other factors affect the duties and authorities of Immigration such as helping to maintain the sustainable development of scientific and technological progress and the development of cooperation. regional and international, which in turn encourages the increased flow of people into and out of Indonesian territory (Santoso, 2007)

\section{Entry, Existence and Exit from Indonesia}

Entry of foreigners into Indonesia must be in accordance with selective policies, which include entering, residing in, and leaving the territory of Indonesia, based on this principle only foreigners who benefit Indonesia can be granted entry permission, permission to be in Indonesia Meanwhile, for the exit permit, after completing its obligations in Indonesia, then it is allowed to leave Indonesia. Based on the foregoing, in Article 3 of Law number 6 of 2011 it is stated that: to carry out the immigration function, the government establishes an immigration policy where the immigration policy is carried out by the minister who is responsible up to the border of Indonesian territory carried out by Immigration Officers covering the place immigration checks and border crossings. It is emphasized that the Law on Immigration adopts a policy that is selective, namely a policy that examines the arrival, presence and exit of foreigners from Indonesian territory. This policy uses two approaches, namely the Prosperity Approach which examines the extent to which foreigners provide benefits for the nation and the State. The Security Approach, which examines the extent to which foreigners do not interfere with the security and order of society and the State.

Every person who enters or leaves the territory of Indonesia is obliged to go through an inspection conducted by an Immigration Officer at the immigration check point. The examination includes checking travel documents and / or valid personal identity. The documents required to enter, stay and leave the territory of the Republic of Indonesia are a must have state documents such as:

Passport consists of:

Diplomatic passport;

Official passport;

Ordinary passport.
Laksana Passport Travel Letters consist of:

1. Travel Laksana Passports for Indonesian citizens;

2. Travel Letter Like a Passport for Foreigners; and

3. Cross-border travel documents or cross-border passes;

\section{Implementation of Selective Policy (Selective Policy)}

\section{Immigration Service Aspects}

The immigration service aspect implies smoothing and making it easier for people to enter and leave Indonesian territory. The service aspect includes visa exemption arrangements for foreigners from certain countries. These various forms of service are inseparable from the national interest, therefore every ease of immigration given to foreign nationals from one or several certain countries is carried out by as much as possible striving to apply the principle of reciprocity which allows Indonesian citizens to enjoy the same conveniences of the same countries. countries that get immigration facilities in Indonesia (Santoso, n.d.).

Immigration in Indonesia involves 2 (two) things, namely: 1. Intas intas person between the Republic of Indonesia and other countries; 2. Supervision of foreigners residing in the territory of the Republic of Indonesia.

Immigration in Indonesia concerns the entry and exit of the territory of the Republic of Indonesia from people, both Indonesian citizens and foreigners. So every person who enters or leaves the territory of Indonesia, will be related to immigration through a place called the Immigration Checkpoint or also known as TPI, where an inspection is carried out by an Immigration Officer.

\section{Immigration Traffic}

Immigration is closely related to the traffic of people leaving or entering a country and is regulated in Law Number 9 of 1992 which has been amended by Law number 6 of 2011 concerning Immigration which states that immigration regulations which include the traffic of incoming people or leaving the territory of Indonesia is the right and authority of the

Republic of Indonesia and is one of the manifestations of its sovereignty as a constitutional state based on Pancasila and the 1945 Constitution. The document tool commonly used for people who leave or enter a country is a passport, namely a document official travel or travel documents issued by the Government containing the identity of the holder and used to travel between countries according to their interests, for example for official purposes, trade, tourism and others. 39In the event that a person wishes to travel abroad, he must first obtain a permit to enter the country to be addressed through the embassy or consulate general or a 
representative appointed by the country concerned. Permission to enter a certain country is commonly referred to as a "visa" (Soetoprawiro, n.d.).

\section{Examination by immigration officials at TPI with a selective policy}

Based on Law No.6 of 2011 concerning immigration article 1 point 7, Immigration Officers are employees who have gone through special immigration education and have immigration technical expertise and have the authority to carry out duties and responsibilities under the law. And Article 9 paragraph 1 explains that every person who enters or leaves the Indonesian Territory is obliged to go through an examination conducted by an Immigration Officer at an Immigration Checkpoint. In the explanation above, it can be clear that the main task of an immigration official at an immigration checkpoint is to carry out checks on all people crossing into or out of Indonesian territory. In the previous chapter, the author has explained about the Inspection Standard Operations carried out by immigration officials in carrying out immigration checks. For the sake of the safety of the State and the welfare of the nation, Indonesian immigration uses filter politics, (Selective Policy) This means that you must be careful with the permits of foreigners who enter Indonesian territory, that is, only the required experts are allowed to enter, and even then are limited in both the number and length of their stay (Indra, 2010).

So it is appropriate for an immigration official in carrying out his duties to carry out the operational standards of inspection at immigration checkpoints to apply a selective policy to foreign nationals who cross, especially in its application, an immigration official can reject foreigners in the event of irregularities or violations committed by foreigners in accordance by Law number 6 of 2011 concerning immigration article 13 article 1 which reads:

Immigration Officials refuse to enter Indonesian territory if the foreigner:

a) His name is on the list of deterrence;

In Law No. 6 of 2011 on Immigration Determination is a prohibition against foreigners to enter Indonesian territory based on immigration reasons.

b) Do not have a valid and valid Travel Document; Where the Travel Document used must meet the elements of identity, validity and purpose of the trip. In accordance with Law number 6 concerning immigration article 8 paragraph 1 , that every person who enters or leaves the Indonesian Territory is required to have a valid and valid travel document. In his explanation, what is validated is a travel document issued by an authorized official and is still valid for at least 6 (six) months before the validity period ends. a. have fake Immigration documents; the same as the explanation above, Article 8 paragraph 1 explains about travel documents that are valid and still valid, so that if the travel documents of the person making the crossing are declared false, the foreigner concerned will be refused entry to Indonesia. usually the mode used by the Foreigner, namely Impostor, takes advantage of the similarity or disguise of using someone else's passport.

In article 8, paragraph 2, every foreigner is also required to have a valid and valid visa, unless otherwise stipulated by this law and international treaties. So that the visa used by foreigners must be original and still valid.

a. do not have a visa, except those who are exempted from the obligation to have a visa; In the Immigration Law No. 6 of 2011 regarding the General Provisions of article 1 paragraph 18 , it is explained that:Office of Republic of Indonesia Visa, hereinafter referred to as Visa, is a written statement given by an authorized official at the Representativethe Republic of Indonesia or elsewhere as determined by the government of the Republic of Indonesia or in other places determined by the Government of the Republic of Indonesia which makes approval for foreigners to travel to the Indonesian Territory and becomes the basis for granting a Stay Permit.

b. has given incorrect information in obtaining a visa;

In the case of providing information that must be made by a foreigner applying for a visa at a place stipulated by law, the information given by the foreigner must be in accordance with the identity data and the activities that the foreigner will carry out in Indonesian territory. In the case of granting this visa, the officer will also apply a selective policy to foreigners. So that in granting visas, only useful foreigners will be granted visas to Indonesian territory. Data or information provided by foreigners must be correct, because if an error is found, there are indications that the foreigner will carry out activities detrimental to the Indonesian state.

a. suffering from an infectious disease that endangers public health;

$b$, Infectious disease or infectious disease is a disease caused by a biological agent (such as viruses, bacteria or parasites), not caused by physical factors (such as burns) or chemical (such as poisoning). Foreign nationals who have a contagious disease can be refused entry

Indonesian territory, because infectious diseases can disrupt public order in Indonesian territory. 
a. involved in international crime and transnational organized crime;

Free translation of international criminal offense is any action that is implemented in multilateral conventions and is followed by a certain number of participating countries, even though it contains one of the ten characteristics of the crime (Atsmasasmita, n.d.). [Types of International Crime:

1). Genocide Crime (genocide)

Is any act committed with the aim of destroying all or part of a national, ethnic, racial or religious group.

2). Crimes Against

Humanity(crimesagainsthumanity) is any act committed as part of a widespread or systematic attack directed against a civilian population, knowing of the attack.

\section{War Crimes}

In the Rome Statute, War Crimes refers to the Geneva Convention of 12 August 1949, that the following acts against a person's rights or property are protected under the provisions stipulated in the Geneva Convention.

i. included in a list of people seeking arrest from a foreign country;

foreigners who are involved in violations that occur in a foreign country who feel aggrieved by the foreigner concerned.

j. involved in treason against the government of the Republic of Indonesia;

Plot in the Big Indonesian Dictionary is an act (attempt) to overthrow a legitimate government.

j. included in the network of practices or activities of prostitution, human trafficking and people smuggling.

As for the Government Regulation of the Republic of Indonesia Number 31 of 2013 concerning Implementation Regulations of Law Number 6 of 2011 concerning Immigration, Part Three concerning Procedures for Entry and Exit of Indonesian Territory paragraph 4 concerning Refusal to Enter and Exit Indonesian Territory Article 25 paragraph 1 also concerning Immigration Officials refuse foreigners to enter Indonesian territory in the event that the Foreigner:

a. His name is on the list of deterrence;

b. Do not have a valid travel document and are still valid;

c. Possessing Fake Immigration Documents;

d. Do not have a visa, except those who are exempted from the obligation to have a visa;

e. Has provided incorrect information in obtaining a Visa;

f. Suffering from an infectious disease that endangers public health;

g. Involved in international crimes and transnational organized crime; h. Included in the list of wanted persons to be arrested from a foreign country;

i. Involved in treason activities against the Government of the Republic of Indonesia; or

j. Included in the network of practices or activities of prostitution, human trafficking and human smuggling.

\section{Other indicators of the Application of the Foreigner Selective Policy by Immigration Officers at the Checkpoints}

Basically, the implementation of selective policies in effect at the Immigration Office is in accordance with the implementation of the applicable regulations, but apart from foreigners as stated in article 13 of Law No.6 of 2011 and Government Regulation Number 31 of 2013 concerning rejection, indicators of the implementation of selective policies by immigration officials at the Soekarno-Hatta airport immigration checkpoint, it can be seen from other factors related to immigration issues.

Among them:

a. Foreign Citizens from Prone Countries

Based on the Decree of the Minister of Law and Human Rights No.M.HH-02.GR.01.06 of 2017 concerning Calling Visas and Granting Visas to Citizens of Calling Visas in 9 countries, namely: Afghanistan, Guinea, Israel, North Korea, Cameroon, Liberia, Nigeria and Somalia. Foreign nationals who come from prone countries need a Calling Visa, which is a visa submitted by the foreign national concerned which is directly addressed to the Director General of Immigration for approval. So that if a foreigner who comes from a prone country uses an invalid visa, immigration officials can refuse the foreigner concerned.

b. Early Detection of Abuse of Stay Permits in Indonesian Territory Abuse of residence permits is an activity of foreigners that is not in accordance with the residence permit granted by immigration officials (Indonesian government), for example, a residence permit that is granted in the form of a tourist stay permit, but the foreigner concerned carries out work activities. in Indonesian territory. Immigration Officers can conduct "in-depth interviews" to ask the destination of foreigners who enter Indonesian territory, this indication can be clarified by identifying the documents below:

1. Travel Documents (Passport and Visa)

An indication of abuse of residence permits in Indonesian territory is by looking at the Travel Documents of foreigners who will carry out activities in Indonesian territory. Visas and Passports are 2 documents that must be 
observed in this early detection, where we have to read the crossing data in the passport, which country does it go to ?, were there any crossings carried out in Indonesia before? And we can conclude what activities what will be done in Indonesia when the foreigner makes a crossing at this time, according to the visa that the foreigner is using.

2. Return Tickets orTickets

Selective Indication Passthat immigration officials can use from the return ticket inspection, namely by returning tickets immigration officials can find out the return of foreigners who carry out activities in Indonesian territory. so as to prevent overstay for foreign nationals who are in Indonesia. In the Immigration Regulations also a Return Ticket is a requirement for applying for a Visit Visa to Indonesian territory.

3. Proof of Having a Cost of Living

The requirement for foreigners to enter Indonesian territory in the application for a visit visa is that they have proof of having the cost of living for themselves and / or their families during their stay in Indonesian territory. immigration officials have the right to ask foreigners for information regarding the amount of cash they have kept, for the purposes of identifying foreigner activities in Indonesian territory and also idenification of abuse of residence permits for the foreigner concerned, if the foreigner argues that he is on vacation in Indonesian territory but with little money, hence the identification of misuse of residence permit needs to be explored by the foreigner concerned.

4. Hotel Booking (lodging reservations)

Things that can be identified from foreigners in terms of doing activities in Indonesia are hotel bookings, by looking at hotel bookings we can also find out how long foreigners will stay in Indonesia, and we can also identify where foreigners live (hotel area) to do activities in Indonesian territory. So that it makes it easier to interview foreigners to find out early activities of foreigners in Indonesian territory.

c. Attitudes of Foreigners' Behavior When Examination at TPI.

In the case of the implementation of selective policies, the need for a good attitude by foreigners in carrying out the Audit, in the event that the foreigner when the examination is carried out does not cooperate or commit acts of violence, humiliates the officer (immigration official), is unconscious (drunk), so that he can carry out activities that are dangerous and should be suspected of endangering security and public order or not respecting or obeying laws and regulations. Then the foreigner can be refused entry into Indonesian territory.

In the event that the Immigration Officer refuses the Foreigner as intended, the Person in Charge of Transport Equipment is obliged to bring back outside the Indonesian Territory at the first opportunity the Foreigner to the country of last departure. Rejection as referred to is carried out by affixing a stamp on the relevant Travel Document or submitting a letter of rejection to the Person in Charge of Transport Equipment.[6]

\section{Forms of the Selective Policy on the sign of} leaving people from the territory of Indonesia

\section{Regulations for granting exit sign permits}

In Law No.6 of 2011 concerning Immigration, it regulates the sign of leaving Indonesian territory; Article 15

Every person can leave the territory of Indonesia after fulfilling the requirements and obtaining an Exit Sign from the Immigration Officer; Article 16

(1) The Immigration Officer refuses a person to leave the Indonesian Territory if that person: a.

Does not have a valid and valid travel document; b. required for the purposes of investigation and investigation at the request of the competent official; or

c. his name is listed in the Prevention list

(1) Immigration Officials also have the authority to refuse foreigners to leave the Indonesian Territory in the event that the Foreigner still has obligations in Indonesia which must be resolved in accordance with the provisions of laws and regulations

The activity of giving an exit sign has clearly with the authority of immigration officials who have met the requirements will get an exit sign who has fulfilled the obligations in accordance with the laws and regulations, in other circumstances refusal can also be done as described in the Government Regulation of the Republic of Indonesia No.31 of 2013 concerning implementation of Law No.6 of 2011 concerning immigration;

\section{Article 28}

c. Immigration officials have the authority to refuse a person to leave Indonesia's territory in the event that the person: 
a. does not have a valid travel document and is still valid;

b. required for investigation purposes at the request of the competent official; or

c. his name is on the preventive list.

d. Immigration Officers also have the authority to refuse foreigners to leave Indonesia's territory in the case that foreigners still have obligations in Indonesia that must be completed in accordance with statutory provisions.

The examination of Outgoing Persons has been regulated in the Regulation of the Minister of Law and Human Rights No.44 of 2015 concerning the procedures for Examination in and out of Indonesian territory at the Immigration Checkpoint

\section{Procedure for the departure of people outside of Indonesia}

Immigration checks at TPI Air can be divided into completing the departure of Indonesian citizens and foreigners, and transportation crew. Settlement of Indonesian citizens' departure at TPI Air, including the initial steps for counter officers to receive DPRI and boarding passes to destination countries from Indonesian citizens and checking boarding passes and citizen identities Indonesia which is adjusted to the DPRI (Republic of Indonesia Travel Document) owned. The main step for counter officers is scanning the DPRI of Indonesian citizens on the preventive list through the Border Control Management (BCM) system and applying an exit stamp and initial officers at the DPRI citizen. Furthermore, the final step of the officer is to recapitulate immigration settlement activities and handle non-conformities at the TPI (Regulation of the Minister of Law and Human Rights of the Republic of Indonesia Number 44 of 2015, n.d.).

Fig. 1. Procedure for completing international departures for Indonesian citizens

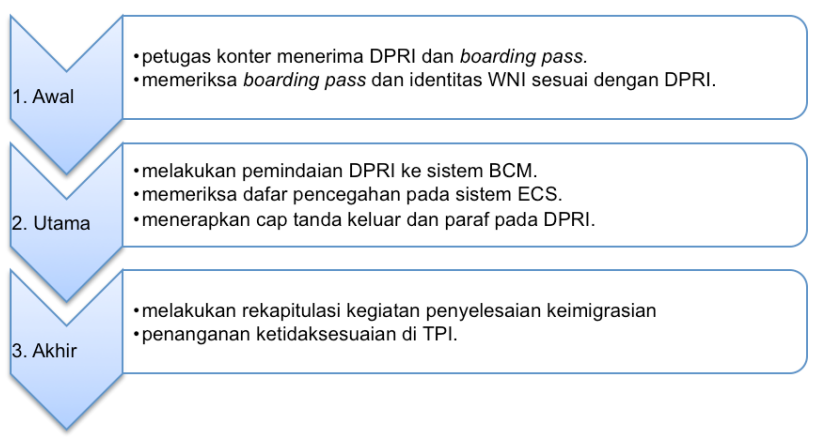

Source: Regulation of the Minister of Law and Human Rights of the Republic of Indonesia Number 44 of 2015 Completion of the departure of foreigners at TPI Air, including the initial steps for counter officers to receive Foreign Country Travel Documents and boarding passes to the destination country from Indonesia according to the foreign country's travel documents held. The main step for counter officers is scanning the travel documents of foreign nationals on the preventive list through the Border Control Management $(\mathrm{BCM})$ system. It is necessary to pay attention to the valid residence permit and the period of stay /overstay. After that the officer applies the exit stamp and the official initials on the travel documents of the foreign nationals of the foreign country. Furthermore, the final step of the officer is to recapitulate the activities of settling immigration and handling nonconformities at the TPI.

Fig. 2. Procedure for settling international departures for foreigners

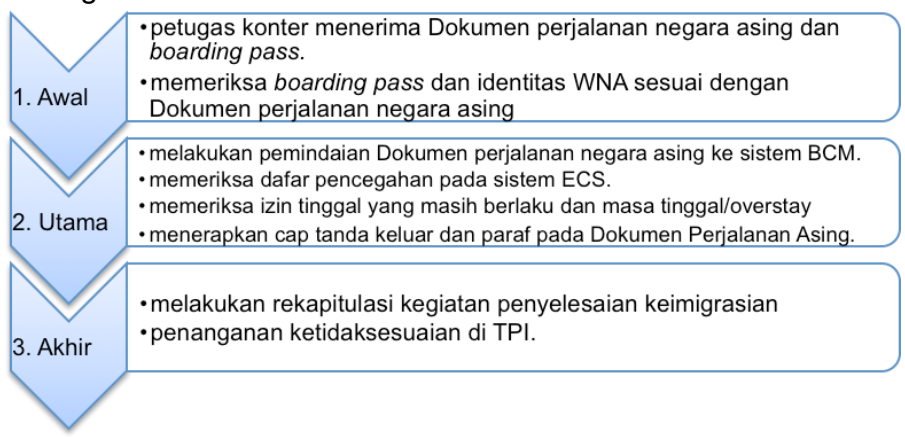

Source: Regulation of the Minister of Law and Human Rights of the Republic of Indonesia Number 44 of 2015 At the time when the author carried out the Field Work Practice at the examination site, he implemented an examination in accordance with the applicable SOP, but of course there were still many obstacles experienced by immigration officers in implementing selective policies, Therefore, it is necessary to improve the system and also to implement efficient working hours, making it easier for officers to carry out inspections

\section{The review of the number of departure preventions for Indonesian citizens is related to the selective policy at the TPI.}

In terms of immigration checks, Indonesia has existed since the Dutch colonial era. At that time, there was a colonial government agency called Immigratie Dienst which was in charge of handling immigration issues for the entire Dutch East Indies region. Indonesia became independent on 17 August 1945, but it was not until 26 January 1950 that the Immigratie Diens was received from

$\mathrm{H}$. Breekland to the new Head of the Immigration Service, Mr. HJ Adiwinata. Considering the acceptance is not only as a replacement for the leadership of the Immigration bureau from the hands of the Dutch government to the hands of the Indonesian government, but more importantly this transition is the starting point of a new era in the politics of Indonesian immigration law, namely the change from thepolitics of immigration law. open doorpolicy) in the interests of the colonial government, becoming a selective immigration law(spolicyelective policy) based on Indonesia's national interests 
This policy uses two approaches, namely the Prosperity Approach and the Security Approach.51 In the sign of exit without us knowing there is a Selective Policy policy using two approaches, namely the Prosperity Approach and Security (Security Approach) in the case that only people are useful for their welfare to meet the necessities of life according to procedures and do not endanger the interests of the state after carrying out obligations while in the territory of Indonesia, an exit sign can be given by immigration officials.

According to Yulianto Bima Negara, "The meaning of the Selective Policy in the field of immigration is a policy of the Indonesian government against the entry of foreigners into Indonesian territory based on the principle of benefit in the sense that only foreigners are beneficial to the people, not dangerous to the nation and state and provide a sense of security to be allowed to enter the territory. Indonesia by paying attention to the security approach (security approach) and the welfare approach (prosperity approach), immigration officials as executors in terms of checking entry signs and there are also those who go out seeing the facts on the ground that not all people get a sign in the form of a stamp from immigration officials can be categorized as filter from selective policy " 52

In immigration there are Immigration Functions, namely:

1.Community Service: Functionsfunctions of government administration or state administration that reflect aspects of service. In this aspect, immigration is required to provide excellent service in the field of immigration to both Indonesian citizens and foreign citizens. In this activity, it can be seen when people who are going to enter or leave the Indonesian Territory who are in accordance with the procedure, after being checked, will get services by immigration officials.

b. Law Enforcement: in carrying out immigration duties, the entire immigration law rule is enforced to every person who is within the jurisdiction of the Republic of Indonesia. In the implementation of this law enforcement function, operationally it can be divided into two, namely administrative law enforcement (immigration action) and proactive law enforcement, namely investigative authority, including investigative tasks (summons, arrest, detention, examination, search, confiscation), filing. cases and filing case files to the public prosecutor. The implementation of law enforcement in the selective policy is to prevent leaving according to statutory regulations and being processed according to the rules for violators, such as withdrawal of passports, detention, being subject tofees overstay and others

c. Security Function: Immigration is the guardian of the country's gates, it is said that because immigration is theinstitution first and lastthat screens the arrival and departure of foreigners to and from the territory of the Republic of Indonesia. The implementation of the security function aimed at Indonesian citizens is described through preventive measures abroad, while the implementation of the security function aimed at foreign nationals is defined through the following actions:

1) Conduct a selection of each purpose of arrival of foreigners by examining visa applications;

2) Cooperating with other state security apparatus, especially in providing supervision regarding the enforcement of the immigration law;

3) Performing immigration intelligence operations in the interests of state security and;

4) Implement prevention and deterrence, namely prohibition for a person to leave Indonesian territory within a certain period of time and / or prohibition from entering Indonesian territory within a certain time.

d. Community welfare development facilitator: As one of the programs the immigration government has participated in its function to participate in building community welfare without exceeding the limits of its corridors, to sign out only people who have followed procedures so as not to endanger themselves abroad in order to get a more decent life then according to the designation for using the passport, you will get an exit certificate from the immigration official. To support the selective policy policy, there is an Immigration Function in its implementation, the function of prioritizing the function of law enforcement and the security function (security) which must be prioritized without undermining other functions, namely the function of service and facilitator of community welfare development. Yulianto Bima Negara said that he spoke about the selective policy of people who have been in the territory of Indonesia, foreigners who hold immigration permits such as Visit Permits, Limited Stay Permits, Permanent Stay Permits and other permits granted by Immigration Officers either at the Immigration Checkpoints or at Offices. Immigration throughout Indonesia when they will apply for an extension of their immigration permit, there are things that will filter them and will be reselected until they have completed their obligations also when they leave 
they must be free from overstay (burden costs), behave well while in Indonesia, then Indonesian people who want to leave must also be in accordance with the use of their passports for the occurrence of nonprocedural TKIs, so they must refer to the Circular of the Director General of Immigration Number IMI-0277.GR.02.06 of 2017 concerning the prevention of Non-procedural TKI

Yulianto Bima Negara said talking about selectivity e policy of people who have been in the territory of Indonesia foreigners who hold immigration permits such as Visit Permits, Limited Stay Permits, Permanent Stay Permits and other permits granted by Immigration Officials either at Immigration Checkpoints or at Immigration Offices throughout Indonesia if they will apply for an extension of their immigration permit, there are things that will filter them and will be reselected until they have completed their obligations also when they leave they must be free from overstay (burden costs), behave well while in Indonesia, then also Indonesians who want to leave also must be in accordance with the use of the passport for the occurrence of nonprocedural TKI, it must be guided by the Circular of the Director General of Immigration Number IMI0277.GR.02.06 of 2017 concerning the prevention of Non-procedural TKI

Whereas the facts in the field of departure prevention for Indonesian citizens (WNI) but also foreign citizens (WNA) with various problems that occur, and various varied problems.

Indonesian Citizens (WNI) who are prevented from leaving, can also be based on other indicators, one of which is the Circular of the Director General of Immigration Number IMI0277.GR.02.06 of 2017 concerning the Prevention of Non-procedural Indonesian Workers seeing the rise of Indonesian Citizens Outside The country is a victim of the Crime of Trafficking in Persons (TPPO), prevention efforts become proactive in the technical implementation unit to prevent Indonesian citizens from completing travel documents and who will leave Indonesian territory as stipulated in Article 67 of Law No. 6 of 2011 on Immigration.

Based on the data above, there are several reasons why people were prevented from leaving the territory of Indonesia in the March-April period, there were 50 (fifty) Indonesian citizens who were suspected to be working abroad through incorrect / non-procedural procedures, as many as 2 (two) people due to immigration reasons. according to article 75 (1) Law No.6 of 2011 concerning immigration, then 22 (twenty two) people are included in the blacklist according to Article 91 of Law number 6 of 2011 concerning immigration including coordination of related institutions and synergy between government agencies, and each of 1 (one) person is suspected of using a fake passport, tampering with entry / exit signs, possessing multiple passports in accordance with article 126 letter d Law number 6 of 2011 on immigration and DPO (list of wanted persons) by the police according to article 91 paragraph 2 letter c Law number 6 of 2011 concerning immigration.

There are many preventions of departure for Indonesian citizens with the highest number of violations, that is, it is suspected that TKI will work abroad nonprocedurally occupying the highest percentage of 55 (fifty five) people.

In the prevention of non-procedural TKI, there is a circular of the Director General of Immigration number IMI-0277.GR.02.06 of 2017 with the aim of prevention during the issuance process and / or immigration checks at the Immigration Checkpoint.

In its implementation, the circular requesting the Head of the Immigration Office in charge of the Immigration Checkpoints under him to carry out a careful and selective examination of the formal requirements and material correctness attached to the passport application and immigration inspection process at the TPI by prioritizing thesense of security.

Increase awareness of every Indonesian citizen who is suspected of working abroad (nonprocedural TKI) on the grounds of the Hajj / Umrah pilgrimage, apprenticeship program for special employment exchanges, scholarships, placement of migrant workers and cultural ambassadors.

Optimizing the supervisory function for every Indonesian citizen at both the Immigration Office and the TPI in the framework of the occurrence of Non-procedural TKI, if based on the results of the examination it is strongly suspected that the occurrence of Non-procedural TKI so as not to hesitate to refuse.

Seeing the facts on the ground, in principle, immigration officials are examining those intending to leave Indonesian territory. Theoutput resultingis a sign of exit The

number of Indonesian citizens who are rejected at the time of departure associated with the selective policy, this is quite illustrative that the policy exists at the time of departure to leave the territory of Indonesia, which in fact not everyone gets an exit sign in the form of a stamp, this is an activity that is do immigration officials who are classified 
aspolicy selectivepolicy based approach to security(security)and a welfare(prosperity)in the framework of upholding the sovereignty of Indonesia.

\section{CONCLUSION}

Whereas the large number of preventions when leaving the territory of Indonesia is the role of immigration officials, including the selective policy in the framework of state security (security) and prosperity (prosperity) to maintain the upholding of state sovereignty;

a. Security, namely helping to maintain state security by coordinating with relevant agencies, playing a role in preventing the departure of police DPOs that are included in the blacklist, and preventing the use of fake passports to maintain state sovereignty and ensure that only Indonesian labor migrants comply with procedures to live and work safely in country of destination.

b. Welfare (prosperity) only workers who through the procedure according to the rules, so as to maintain the good name of Indonesia to work in Abroad, get a job, a decent income for itself and can add to foreign exchange for the country

\section{REFERENCES}

Arifin, Ridwan. (2018). Refusal of Foreigners to Indonesia through Immigration Checkpoints at International Airports: Absolute Sovereignty.
Immigration Scientific Journal.

Atsmasasmita. (n.d.). Transnational Crime in the Indonesian Criminal Law system.

Immigration, Law on. (n.d.). Law no. 6 of 2011, LN of 2011 Number 52. , Article 75 paragraph (1) and Part One Explanation.

Indra, Muhammad. (2010). Perspective of Law Enforcement in Indonesian Immigration Law. Jakarta: directorate general of immigration.

Regulation of the Minister of Law and Human Rights of the Republic of Indonesia Number 44 of 2015. (n.d.). Concerning Procedures for Checking the Entry and Exit of Indonesian Territories at Immigration Checkpoints.

Santoso. (n.d.). Immigration Perspective in Economic Development and National Resilience.

Santoso, Iman. (2007). Immigration Perspective in the United Nation Convention Against Transational Organized Crime. Jakarta: Perum Percetakan Negara RI.

Sfahriful, Abdullah. (n.d.). Introducing Immigration Law. Jakarta: Grafika Indonesia, nd.

Soetoprawiro, Koerniatmanto. (n.d.). Indonesian Citizenship and Immigration Law. Jakarta: Gramedia, 1996.

\section{Copyright holder:}

Syakir (2020)

First publication right :

Journal of Social Science

This article is licensed under:

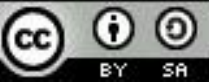

